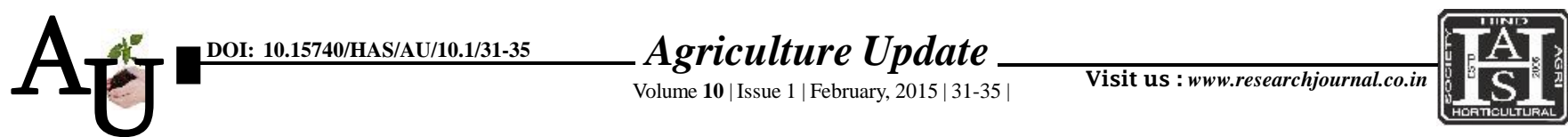

- ISSN-0976-6847

\title{
Research Article: Role of farm women in agricultural activities
}

\author{
ANURADHA RANJAN KUMARI* AND LAXMIKANT
}

Article Chronicle :

Received :

15.12.2014;

Revised :

28.12.2014;

Accepted :

14.01.2015

Key Words :

Agricultural activities, Role of farm women, Invisible workers
SUMMARY : Women play a significant and crucial role in agricultural development and allied fields. It is most unfortunate that the role of women in agricultural has not highlighted. By and large they have remained as invisible workers. Therefore, efforts were made to role of farm women in agricultural activities. The study was undertaken in Deoria district of U.P. during 2013-14. The data were collected from 180 farm women by adopting the proportionate random sampling method. The results of study revealed that under agriculture related task, the data reveals that drying, cleaning, storage of grains and processing of farm produce were the major farm operations where in women role was cent per cent. In the terms of decision making majority of farm women did not take any decision single handly. Farm women took single hand decision regarding live stock management $(40.55 \%)$ followed by farm supplies and inputs $(28.88 \%)$, area for different crops $(18.88 \%)$, maintenance of implements $(14.44 \%)$, labour management $(12.22 \%)$, capital management $(9.44 \%)$, and marketing of agricultural produce only 8.88 per cent. It could be concluded that the women of Deoria district of U.P. state were highly involved in all agricultural practice. So, it is need to develop suitable, strategy training to women about modern technologies to make them more skilled for agricultural production.

How to cite this article : Kumari, Anuradha Ranjan and Laxmikant (2015). Role of farm women in agricultural activities. Agric. Update, 10(1): 31-35.

Author for correspondence :

ANURADHA RANJAN

KUMARI

Krishi Vigyan Kendra, Indian Institute of

Vegetable Research,

Malhana, DEORIA(U.P.)

INDIA

Email: anuradha_rau@

rediffmail.com

See end of the article for

authors' affiliations 